\title{
FORMA VĚTY A JEDNOTA POJMU K systematickému kontextu teorie predikace a spekulativní věty v předmluvě k Fenomenologii ducha
}

\section{Jindřich Karásek}

Teorie tzv. spekulativní věty patří k nejobtížnějším součástem Hegelovy logiky. Hegel jí věnuje rozsáhlejší pasáž v předmluvě k Fenomenologii ducha.Záměrem následujících úvah je pokusit se o ucelenou interpretaci této patrně nejkomplikovanější pasáže z předmluvy a objasnit její celkový systematický kontext. Omezíme se jen na text předmluvy.Způsob, jak Hegel koncepci spekulativní věty rozvíjí ve Vědě o logice, necháme stranou. Ukáže se, co Hegel míní, když má za to, že normální věta není schopna vyjadřovat spekulativní pravdy.

\section{Tři formy myšlení}

Základním kontextem, ve kterém Hegel v předmluvě koncepci spekulativní věty rozvíjí, je rozlišení tří druhů myšlení. Prvním druhem je formální myšlení. To je charakterizováno tím, že „rezonuje sem a tam (hin und her) v neskutečných myšlenkách“. ${ }^{1}$ Termín „,rezonovat“ má pejorativní konotaci. ${ }^{2}$ Hegel jím míní to, co bychom mohli předběžně

1 G. W. F. Hegel, Phänomenologie des Geistes, in: týž, Werke, III, vyd. E. Moldenhauer - K. M. Michel, Frankfurt a. M. 1970, str. 56. Fenomenologii ducha budeme citovat ve vlastním překladu podle uvedeného vydání.

2 Ve spisu Sonnenklarer Bericht z r. 1801 zdůrazňuje Fichte význam zkušenosti z hlediska našeho vědění: nemáme ,vůbec nic pravdivého a reelního kromě zkušenosti, jež je přístupná každému“. Srv. J. G. Fichte, Sonnenklarer Bericht an das grössere Publicum, über das eigentliche Wesen der neuesten Philosophie. Ein Versuch, die Leser zum Verstehen zu bringen, in: Fichtes Werke, II, Zur theoretischen Philosophie, vyd. I. H. Fichte, Berlin 1971, str. 332. Proti tomu kontrastuje filosofii, ve které si filosof mohl vymyslet (erraisonieren) boha a nesmrtelnost, a takto si moudře a dobře rozumovat (vernünfteln) (tamt., str. 331). Zdá se tedy velmi pravděpodobné, že termín ,rezonovat“ přejímá Hegel od Fichta, a to dokonce ve stejném systematickém kontextu. Je však třeba upozornit na to, že termín „rozumovat“ (vernünfteln) používá Kant pro označení nesprávného používání rozumu (Vernunft) v metafyzice. Systematický kontext je tedy kantovský. Je jím kritika metafyziky. 
označit jako plané rozumování, jež se pohybuje v sobě samém a operuje s myšlenkami, které Hegel označuje jako neskutečné. Můžeme rovněž předběžně přijmout, že tím míní takové myšlenky, jež nemají vůbec žádnou nebo velmi problematickou referencialitu. ${ }^{3}$ To je patrné, když Hegel toto rezonování v neskutečných myšlenkách označuje jako „svobodu od obsahu“. Druhým typem myšlení je myšlení materiální. Hegel je charakterizuje jako „Zvyk běžet vpřed podél představ“ (an Vorstellungen fortzulaufen). Toto myšlení je tedy poháněno představami a je „,nahodilým vědomím, jež je do obsahu pouze ponořeno" a pro něž je obtížné, „vyzvednout z materie zároveň čistě své Já (Selbst) a být u sebe“. Jedná se tedy o myšlení, které nemá schopnost reflexivního odstupu vůči představám.

Je patrné, že se jedná o protikladné formy myšlení: zatímco formální myšlení se od obsahů představ odpoutává zcela a nedbá ho, je materiální myšlení obsahem představ zcela zahlceno, takže se z něho nemůže dostat k tomu, co tvoří základ myšlení, totiž k myslícímu Já. Jaký je vztah formálního myšlení k myslícímu Já, se zde zatím nedá rozhodnout. Dostaneme se k tomu později. Podstatné nyní je, že terapie obou dvou deficientních forem myšlení také musí být protikladná: zatímco materiální myšlení se vyléčí tím, že prostředkem, jímž je pojem, bude přerušeno jeho pobíhání podél představ, ono „Fortlaufen an den Vorstellungen“, a že se vynoří ze své ponořenosti do obsahu, aby se mohlo podívat na břeh, jímž je myslící Já, formální myšlení musí být vyléčeno tím, že přestane „,být libovolným hybným principem obsahu, svou svobodu opět vnoří do obsahu, nechá obsah pohybovat prostřednictvím svého Já jako svůj obsah a bude pozorovat tento pohyb“. ${ }^{4}$ Formální myšlení tak

3 To je jen předběžné vymezení, protože problematika referenciality myšlenek není pro Hegela na rozdíl od Kanta klíčovým problémem. Myšlenková určení rozvíjená ve vědě o logice mají referencialitu zajištěnou Fenomenologií ducha. V úvodu do Vědy o logice Hegel píše: „Ve Fenomenologii ducha jsem předvedl (dargestellt) vědomí v jeho pohybu vpřed od prvního bezprostředního protikladu mezi ním a předmětem až $\mathrm{k}$ absolutnímu vědění. Tato cesta prochází všemi formami vztahu vědomí k objektu a za svůj resultát má pojem vědy. Tento pojem zde tedy nepotřebuje ... žádné oprávnění, protože se mu ho dostalo tam." Srv. G. W. F. Hegel, Wissenschaft der Logik, I, Die Lehre vom Sein, in: týž, Gesammelte Werke, XXI, vyd. H.-J. Gawoll, Hamburg 1990, str. 32. Tato forma transcendentální dedukce jakožto důkazu oprávněnosti (questio iuris) se vztahuje nejen na samotný pojem vědy, ale také na všechny pojmy, které jsou v rámci této vědy rozvíjeny, jak je to zřejmé ze závěru Fenomenologie ducha, kde Hegel explikuje, že podoby vědomí se při dosažení absolutního vědění proměňují v pojmy. K tomu srv. níže.

4 G. W. F. Hegel, Phänomenologie des Geistes, str. 56. 
přestane nakládat s myšleným obsahem dle své libovůle a začne respektovat jeho imanentní strukturaci. To však nemá znamenat, že by se obsah pohyboval zcela sám. Je to vždy myslící Já, jež je principem pohybu obsahu, protože v opačném případě by přešlo ve svůj protiklad a stalo by se materiálním myšlením, jelikož by bylo zcela strháváno a pohybováno obsahem. Nemá s ním však nakládat dle své libovưle, nýbrž má ho svým myslícím Já jen doprovázet, abychom použili Kantovu metaforu, tj. připisovat si ho jako svůj obsah a v tomto připisování pouze pozorovat jeho imanentní pohyb. Zdůrazněme, že formálním myšlením nemá Hegel na mysli Kantovu transcendentální apercepci, nýbrž naopak, ona má být prostř̌edkem jeho terapie. ${ }^{5} \mathrm{~S}$ Hegelem tak můžeme nahlédnout, proč Kant zavádí pro její explikaci metaforu doprovázení: Já myslím má

5 Hegelův vztah ke Kantovi, zejména k jeho projektu tzv. transcendentální logiky, zkoumá B. Longuenesse, Hegel's Critique of Metaphysics, Cambridge 2007, str. 202-214. Autorka se zabývá rovněž otázkou Hegelovy interpretace Kantovy koncepce syntetických soudů a priori ve Víre a vědění (tamt., str. 193-202). Obecně lze říci, že při interpretaci Hegelových textů průběžně srovnává Hegelovy a Kantovy koncepce. Autorka oprávněně zdůrazňuje, že v rámci své rehabilitace metafyziky se Hegel nevrací k předkantovské metafyzice (tamt., str. 15). Autorka upozorňuje na tezi Richarda Kronera, podle níž je Hegelova filosofie pokusem vyřešit rozpory otevřené transcendentálním idealismem (tamt.). A nakonec, z hlediska našeho zkoumání je podstatný její poukaz k tezi Jeana Hyppolita, podle které vyrůstá Hegelova logika z Kantovy transcendentální logiky: Hegel se nevrací k dřívějšímu dogmatismu, nýbrž rozšiřuje transcendentální logiku na logiku dialektickou (srv. tamt.). Autorka sama upozorňuje na okolnost, že nauka o pojmu, třetí část logiky, začíná dlouhou diskusí Kantovy transcendentální logiky. Důvodem podle autorky je, že Hegelova logika je od začátku až do konce - doslova - transformací transcendentální logiky (srv. tamt., str. 16). Podle Horstmanna kladl Hegel důraz na to, že jeho teorie logiky je zásadním přepracováním Kantovy nauky o kategoriích: s Kantem se shoduje v tom, že pojem předmětu je konstituován kategoriálně, odlišuje se od něj v otázce odvození kategorií. Zatímco Kant je chce odvozovat z forem soudů, Hegel je získává sebegenerativním postupem. Srv. R.-P. Horstmann, Hegel über Unendlichkeit, Substanz, Subjekt. Eine Fallstudie zur Rolle der Logik in Hegels System, in: Internationales Jahrbuch des Deutschen Idealismus/International Yearbook of German Idealism, 1, 2003, str. 190. Podle Wernera Beierwaltese lze jako dějinný výkon Hegelovy logiky prokázat to, že syntetizovala do jednotné teorie otázky po transcendentalitě vědomí či myšlení s otázkami onto-theologie. Srv. W. Beierwaltes, Identität und Differenz, Frankfurt a. M. 1980, str. 243, pozn. 4. Rozdíly mezi Kantovou a Hegelovou koncepcí kategorií analyzuje Konrad Cramer. Srv. K. Cramer, Spekulatives Denken und synthetisches Urteil a priori, in: Zeitschrift für philosophische Forschung, 4, 51, 1997, str. 507-536. Srv. také K. Cramer, Kant oder Hegel. Entwurf einer Alternative, in: D. Henrich (vyd.), Kant oder Hegel? Über Formen der Begründung in der Philosophie. Stuttgarter Hegel-Kongress 1981, Stuttgart 1983, str. 140-148; D. Henrich, Kant und Hegel. Versuch zur Vereinigung ihrer Grundgedanken, in: týž, Selbstverhältnisse, Stuttgart 1982, str. 173-208. 
představy jen doprovázet, tj. připisovat si je jako své představy, a nemá intervenovat do jejich obsahu. V tomto ohledu je obsahová prázdnota jeho výhodou.

Proti těmto deficientním formám myšlení, jež vyžadují uvedenou terapii, staví Hegel formu myšlení, kterou označuje jako uchopující myšlení - das begreifende Denken. ${ }^{6}$ Hegel je charakterizuje negativním vymezením vůči myšlení formálnímu, přičemž nejprve učiní explicitním ten moment, který při prvotní charakterizaci formálního myšlení nechal stranou. Činí tak v termínech pozitivity a negativity. Z hlediska těchto termínů je pro formální myšlení charakteristický pouze negativní vztah k obsahu, který nevede ke konstituci nové pozitivity. Aby tedy mohlo nahradit negovaný obsah nějakým novým obsahem, „musí být vzato odněkud něco jiného“. $7 \mathrm{Z}$ tohoto důvodu je formální myšlení „reflexí do prázdného Já“, tj. na základě negace obsahu, která neústí sama od sebe do nového pozitivního obsahu, je získáno jen prázdné Já, v němž je vyjádřena nejen nicotnost (Eitelkeit) jeho vědění, ale i nicotnost „tohoto náhledu“, 8 tj. nicotný není jen obsah, ale i náhled, že obsah je nicotný. Zdá se tedy, že Hegel chce naznačit, že pro reflexí získané prázdné Já je vše nicotné. To by odpovídalo popisu, který Hegel podává o absolutní svobodě jakožto té podobě vědomí, do které ústí osvícenské vzdělání vědomí (Bildung), pro něž nemá ani smrt „vnitřní obsah a náplň; nebot' to, co je negováno, je nevyplněný prázdný bod absolutně svobodného Já“. ${ }^{9}$ Hegel tímto popisem nemá na mysli nějakou konkrétní filosofickou pozici, nýbrž vývoj novověkého ducha vcelku. ${ }^{10}$ Pokud dáme toto místo do souvislosti s interpretovanými místy z předmluvy, ukáže se opět, že

6 Tento termín by bylo možné alternativně překládat také jako pojmové nebo rozumějící myšlení.

7 G. W. F. Hegel, Phänomenologie des Geistes, str. 56.

8 Tamt.

9 Tamt., str. 436.

10 Tento vývoj Hegel neodsuzuje, nýbrž právě naopak ho chápe jako nutný, nebot' jen jeho prostřednictvím lze odstranit rozdvojení ducha na svět vzdělání (Welt der Bildung) a svět víry (Welt des Glaubens). Toto rozdvojení je překonáno osvícenstvím jakožto pohybem, na základě něhož se skutečnost rozdvojená na „Diesseits“ a „Jenseits“ navrátí zpět do jednoty sebevědomí, uchopující se v moralitě jako skutečné Já (Selbst) (G. W. F. Hegel, Phänomenologie des Geistes, str. 327). Zde je patrné, že překonáním reflexe do prázdného Já, do něhož osvícenství vyústí, je Kantova teorie svobodné vůle, která již není absolutní svobodou do sebe se reflektujícího prázdného Já, nýbrž je autonomií, a podléhá tudíž zákonům, které si sama dává. V interpretovaných místech v předmluvě rozvíjí Hegel tuto souvislost ve velmi rudimentární podobě v rámci výlučně epistemického kontextu spekulativní věty. 
formálním myšlením nemá Hegel na mysli Kantovu transcendentální apercepci. Ta je sice na obsah zcela prázdnou představou, vyjádřenou ve větě ,Já myslím“, avšak smyslem aktu doprovázení není negace obsahů, k nimž se vztahuje, aby se tak mohla neustále jen vracet ke své prázdnotě, nýbrž připsání si obsahu jako svého obsahu a na základě toho jeho spojení do jednoty předmětu zkušenosti. Jedná se tedy přímo o protikladný akt, než je akt prosté negace obsahu.

Z důvodu onoho čistě negativního typu negace není formální myšlení „ve věci, nýbrž již vždy nad ní (darüber hinaus)“, a namlouvá si proto, že „potvrzením své prázdnoty (Behauptung der Leere) je vždy dál než obsahově plný vhled (inhaltsreiche Einsicht)“. ${ }^{11} \mathrm{~V}$ uchopujícím myšlení naproti tomu patří „,negativno k obsahu samému.“ Negativno je v tomto typu myšlení ,pozitivnem, a to jak jakožto jeho imanentní pohyb a určení, tak také jakožto jeho celek.“ Jak jsme již viděli, uchopující myšlení si připisuje obsah jako svůj obsah, do obsahu však neintervenuje, nýbrž pouze pozoruje jeho imanentní rozvoj, a ten je takového druhu, že se vztahuje k sobě ve formě negace, na základě které vzniká nový pozitivní obsah. Negativno totiž patří k obsahu samému a je také jeho imanentním pohybem a určením. To znamená, že na základě tohoto pohybu, jehož hybatelem je negativno, nabývá obsah sám na určitosti. Důraz na termín „,celek“ lze interpretovat jako poukaz k tomu, že negace se nezaměřuje jen na nějaké dílčí momenty obsahu, nýbrž na tento obsah vcelku, z čehož pak rezultuje nový pozitivní obsah jako celek.

Připomeneme-li si, že tuto úvahu rozvíjí Hegel v předmluvě k $\mathrm{Fe}$ nomenologii ducha, můžeme ji chápat jako vylíčení toho, co se v tomto spisu odehrává: je postupným rozvojem stále nových podob (Gestalten) vědomí, jehož motorem je určitá negace (bestimmte Negation), jíž Hegel připisuje v úvodu tytéž parametry, o nichž hovoří zde. Vědomí samo na sobě přezkoumává své vědění, a to nikoliv v jeho dílčích aspektech, nýbrž jako celek. Na základě tohoto přezkoumávání zjišstuje, že to, co původně považovalo za bytí předmětu o sobě, tj. za bytí předmětu jako nezávislého na vědomí, je jen jeho bytím o sobě pro ně. Toto zjištění vede vědomí $\mathrm{k}$ tomu, že musí změnit své vědění jako celek. Fenomenolog tomuto procesu pouze přihlíží, jak zní známá Hegelova teze, ${ }^{12}$ zatímco obsah - podoby vědomí - se rozvíjí sám. To znamená, že toto přihlížení má analyzovaný charakter uchopujícího myšlení - pojem uchopujícího myšlení má tedy i tuto metateoretickou aplikaci.

\footnotetext{
11 G. W. F. Hegel, Phänomenologie des Geistes, str. 57.

12 Tamt.
} 
Zde je třeba zmínit, že v úvodu do Vědy o logice identifikuje Hegel uchopující myšlení jako její předmět. ${ }^{13}$ Podíváme-li se na tuto souvislost z hlediska závěru Fenomenologie ducha, získá termín „,begreifendes Denken“ ten smysl, že všechny podoby vědomí se proměňují v pojmy (Begriffe), jejichž rozvíjením je Věda o logice. Fenomenologie ducha je filosofická teorie, ve které jsou momenty pohybu ducha, jež jsou původně určitými podobami vědomí (bestimmte Gestalten des Bewusstseins), uchopeny jako určité pojmy (bestimmte Begriffe), a to na základě toho, že diference předmětu či pravdy a vědění, která je definitorní pro vědomí, se navrátila zpět do Já (Selbst), předmětná forma pravdy a vědoucího Já je sjednocena do bezprostřední jednoty, kterou Hegel označuje jako absolutní vědění. Individuální vědomí se sice může dál pohybovat v tomto rozdvojení, avšak fenomenologická věda jakožto uchopující myšlení vidí, jak jednotlivé určité podoby vědomí přešly do podoby určitých pojmů. V úvodu do Fenomenologie ducha označuje Hegel tuto metateoretickou rovinu jako „náš příspěvek“ (unsere Zutat). ${ }^{14}$

\section{Subjekt a akcident}

Vrat'me se však nyní k tématu tohoto pojednání, k problému spekulativní věty, jak ho Hegel exponuje v předmluvě. Samotnou expozici sledovaného problému otevírá Hegel tematizací ,jiné stránky“, která uchopujícímu myšlení jeho uchopování ztěžuje. ${ }^{15}$ Tato jiná stránka má přitom vyplývat z toho, že uchopující myšlení má obsah, at' už jde o představy, myšlenky nebo o jejich směs (Vermischung). Dává ji však do souvislosti s již dříve rozvinutou úvahou, v níž se zaměřil na podstatu (Wesen) ideje, přičemž ona jiná stránka je výrazem ideje, nakolik je chápána jako pohyb. Tento pohyb je myslícím pojímáním (denkendes Auffassen). Otázkou tedy je, v čem vidí Hegel problém ideje jako myslícího pojímání. Zatím je patrné, že onou jinou stránkou uchopujícího myšlení je myslící pojímání. Uchopující myšlení je tedy z jedné perspektivy myslícím pojímáním. Je tedy nutné vyjasnit, co Hegel myslícím pojímáním míní, aby vposledku mohlo být vysvětleno, proč ztěžuje uchopujícímu myšlení jeho uchopování.

13 Týž, Wissenschaft der Logik. Die Lehre vom Sein, str. 25.

14 Týž, Phänomenologie des Geistes, str. 79.

15 Tamt., str. 57. 
Je velmi dobře možné, že termín „pojímání“ - Auffassen - přejímá Hegel z kontextu Kantovy teorie zkušenosti. Kant ho používá souběžně s latinským ekvivalentem apprehensio v německé podobě Apprehension a označuje jím slučování empirické rozmanitosti do jednoty. Toto slučování je myslícím slučováním tehdy, jestliže je uváděno pod syntetickou jednotu apercepce, přičemž propozici (Urteil) definuje Kant v $\$ 19$ Kritiky čistého rozumu jako způsob, jak je rozmanitost představ (dané poznatky) uváděna pod objektivní jednotu apercepce. ${ }^{16} \mathrm{~K}$ tomuto kontextu Kantovy teorie soudu se ještě vrátíme. Nyní jde o to, že uchopující myšlení je obecně vzato schopností vědomí, a potažmo ducha, proměňovat obsahy v pojmy. To by znamenalo, že myslící pojímání bude znesnadňovat uchopujícímu myšlení převádění obsahů na pojmy. Je třeba se ptát, proč tomu tak má být, a opět: abychom tuto otázku mohli zodpovědět, je především třeba vysvětlit, co je to myslící pojímání.

Pozoruhodná je již jazyková souvislost obou termínů. Termín „myslet“ vystupuje v jednom případě v podobě adjektiva „myslící“ (denkendes Auffassen), v druhém případě jako substantivum „myšlení“ (begreifendes Denken). Myšlení, jež je v případě myslícího pojímání něčím druhotným, se teprve v př́ípadě uchopujícího myšlení stává něčím podstatným. V prvním případě jde o pojímání, jež je charakterizováno jako myslící, ve druhém jde o myšlení samo, jež je charakterizováno jako uchopující, přičemž pojímání (Auffassen) a uchopování (Begreifen), jsou, jak se již ukázalo a jak ještě ukážeme dále, něčím velmi rozdílným. Přitom lze mít za to, že volba těchto termínů je Hegelovou promyšlenou strategií, vyplývající z toho, že myšlení chce přiznat významnější funkci než „nová doba“. Tak v úvodu do Vědy o logice čteme, že stará metafyzika měla o myšlení „vyšší pojem“ než doba nová. „Ona totiž vzala za základ, že to, co je o věcech a na věcech poznáno myšlením, je tím, co je na nich jedině vpravdě pravdivým“ (das wahrhaft Wahre).$^{17}$ Jak ještě ukážeme, bude mít toto pojetí myšlení důležitý důsledek ve vztahu k tomu, co Hegel chápe jako pojem (Begriff). Avšak, pokračuje Hegel dál ve svém dějinně-filosofickém velkovyprávění, ,filosofie se zmocnilo reflektující rozvažování“, jímž míní „abstrahující a rozlišující rozvažování..., jež na svých rozlišeních trvá““. ${ }^{18}$ Termín „rozvažování“ (Verstand) by mohl opět svádět k domněnce, že Hegel zde má na mysli Kanta. Jak bylo však patrné z místa v úvodu do Vědy o logice, Hegelovi

\footnotetext{
16 I. Kant, Kritik der reinen Vernunft, vyd. I. Heidemann, Stuttgart 1966, B 141.

17 G. W. F. Hegel, Wissenschaft der Logik. Die Lehre vom Sein, str. 28.

18 Tamt.
} 
jde o problém metafyziky. Je to metafyzika nové doby, v níž se reflektující rozvažování zmocnilo filosofie, a vztáhneme-li řečené k Hegelově charakterizaci formálního myšlení, bude zřejmé, že jím míní metafyziku „nové doby“, s níž spojuje stejný problém jako Kant, totiž neadekvátní odstup od pojímaných obsahů. Chyba formálního myšlení je komplementární vůči chybě myšlení materiálního. To totiž naopak nemělo vůbec žádný odstup od pojímaných obsahů.

K negativní stránce formálního myšlení, o které již hovořil, připojuje Hegel nyní jeho pozitivní epistemickou stránku. V ní je Já (Selbst) „představeným subjektem, k němuž se obsah vztahuje jako akcident a predikát“. ${ }^{19}$ Subjekt je substrát (Basis), na nějž je obsah připojován a na němž probíhá pohyb sem a tam (hin und wieder). Zdá se tedy, že Hegel má na mysli model subjektivity, který pojímá subjekt jako substanci a obsah jako jeho akcident. Subjekt je myslící substance a jeho myšlenky, v nichž či jejichž prostřednictvím se vztahuje k myšleným obsahům, jsou jeho akcidenty. Takto pojatý subjekt je tedy zároveň subjektem propozice, ve které je na místo gramatického predikátu kladen akcident, totiž prostřednictvím myšlenky myšlený obsah. Myšlenky jsou něčím v subjektu, a tudíž at' už se myslící substance jejich prostřednictvím vztahuje k jakkoliv definovaným obsahům, vztahuje se zároveň vždy k sobě. Každá predikace je tak zároveň sebevztahem. Tento důsledek plyne již z Descartova obratu k subjektu a prochází celým novověkým myšlením. Explicitním ho učiní již Leibniz: aperceptivní monáda, substance, se v predikacích vztahuje k sobě, totiž ke svým percepcím, a připisuje si je jako své, konstituuje vědomí percepcí. ${ }^{20}$ Kant se sám ještě v osmdesátých letech zabýval touto koncepcí, totiž pojmout subjekt jako substanci, jíž její myšlenky inherují jako její akcidenty. Nakonec ji však zavrhnul, a v kapitole o paralogismech Kritiky čistého rozumu podrobil kritice.

Naproti tomu v př́ípadě uchopujícího myšlení je tomu tak, že pojem je ,vlastní podstatou [Selbst] předmětu, jež se podává (darstellt) jako své dění“ ${ }^{21}$ „,Selbst““ - Já, jež jakožto pojem je podstatou předmětu, zde není „klidovým subjektem, jenž nehybně nese akcidenty, nýbrž je svéhybným

19 Týž, Phänomenologie des Geistes, str. 57.

20 Tímto kantovským slovníkem interpretuje Leibnizovo pojetí vztahu apercepce a percepcí Konrad Cramer. Srv. K. Cramer, Jednoduchost, percepce a apercepce. Úvahy o Leibnizově teorii substance jako subjektu, přel. J. Kuně̌, in: Reflexe, 44, 2013, str. 101-126, zejm. kap. VII a VIII.

21 G. W. F. Hegel, Phänomenologie des Geistes, str. 57. 
pojmem, jenž do sebe přijímá zpět svá určení“ “. ${ }^{22} \mathrm{~V}$ tomto pohybu tedy onen nehybný subjekt zaniká. Problémem formálního myšlení je tedy primárně jeho statičnost. Já je nehybným subjektem, který se klade do protikladu vůči dění, probíhajícímu na úrovni obsahu, nebo, jak to formuloval Hegel dříve, stojí vždy již nad obsahem, jenž je jeho akcidentem. V uchopujícím myšlení pak Já sestupuje do obsahu a pohybuje se s ním a v něm jakožto jeho pojem, avšak, jak jsme již viděli, tak, že se v tomto obsahu neztrácí ani do něj neintervenuje, nýbrž připisuje si ho jako svůj obsah a pozoruje jeho pohyb. Svým ponořením do obsahu se nestává materiálním myšlením.

Domnívám se, že toto sebepřipisování má Hegel na mysli, když mluví o tom, že Já do sebe přijímá zpět svá určení. Subjekt se tak už nestaví vůči svému obsahu do distance, a již tedy nemůže mít nějaké jiné akcidenty a predikáty než - doplňme - právě tento obsah, do něhož se noří, a je tak zároveň vyplněn pojímaným obsahem. Z hlediska obsahu to znamená, že jeho „roztroušenost (Zerstreutheit) je tím spojena pod Já.“23 Souvislost je zjevně opět pozitivně kantovská. Termín „roztroušený“ používá Kant sám: beze vztahu k jednomu identickému Já je rozmanitost názoru roztroušená. ${ }^{4}$ Výraz ,,spojena pod Já“ (unter das Selbst gebunden) lze do kantovského jazyka přeložit výrazem ,spojena do jednoty Já“, či přesněji do jednoty sebevědomí.

Zde je zřejmé, že jelikož subjekt vyplňuje obsah a má ho jako svůj predikát, má takto zprostředkovaně sebe sama jako svůj obsah a predikát. Struktura ducha, kterou Hegel explikuje v závěru Fenomenologie ducha, totiž být u sebe sama ve své jinakosti, je tak in nuce přítomna již zde. Tedy opět: problémem modelu, s nímž pracovalo formální myšlení, nebyla okolnost, že predikace měla strukturu sebevztahu. Problémem byla jednak jeho statičnost, jednak to, že se subjekt stavěl vůči svému obsahu do distance, takže nemohl být ve svém obsahu u sebe sama. Uchopující myšlení tedy pracuje s ještě radikálnějším modelem predikace jako sebevztahu než formální myšlení. Vztah predikace a popsaného modelu noření se subjektu do svého obsahu není však zatím ještě vůbec vyjasněn. Již nyní je ovšem patrné, že obsah nemůže být akcidentem a predikátem subjektu, a to bud' vůbec, anebo alespoň ne $\mathrm{v}$ tom smyslu, jak tomu je v případě formálního myšlení. Hegel to na dané úrovni analýzy formuluje tak, že obsah není predikátem subjektu, a tedy jeho akcidentem, nýbrž je samotnou substancí,

\footnotetext{
22 Tamt.

23 Tamt., str. 58.

24 Srv. např. I. Kant, Kritik der reinen Vernunft, B 133.
} 
,je podstatou a pojmem toho, o čem je řeč“ ${ }^{25}$ Výše však - v naší interpretaci - Hegel ř́kal, že podstatou předmětu je „Selbst“ jakožto pojem a Já. Nyní říká, že podstatou a pojmem (Wesen und Begriff) toho, o čem je řeč, je sám obsah. To vypadá na první pohled jako rozpor. Ve skutečnosti jde však u Hegela o sjednocení pojímaného obsahu a pojímajícího Já, takže na jedné straně je sám obsah substancí, a tedy podstatou a pojmem, na druhé straně je podstatou předmětu, tj. obsahu „Selbst“, tedy Já jakožto pojem. Cílem fenomenologie ducha je ukázat a doložit jejich sjednocení, díky němuž je substance subjektem a subjekt substancí, zatímco formální myšlení trvá na jejich ustaveném protikladu. Hegel tak v předmluvě předjímá závěrečný rezultát celého projektu.

Formální myšlení je představující (vorstellend), a to právě proto, že se staví do distance vůči svému obsahu, staví ho před sebe (vor-stellt), a veškerý pohyb je pohybem akcidentů, a tedy predikátů. Ani zde se nesmíme termínem ,představa“ nechat svést k tomu, abychom př́liš uspěchaně vztahovali Hegelovu kritiku k nějaké konkrétní filosofické pozici. Jde totiž spíše o to, že dominantním termínem novověkého myšlení je pojem repraesentatio $\mathrm{v}$ nejrůznějších jazykových variantách. Do němčiny přeložil tento termín již Wolff termínem Vorstellung.$^{26}$ Hegel tak má formálním - představovým - myšlením opět na mysli povahu novověkého ducha vůbec. ${ }^{27}$ Pro abstrahující rozvažování, jež se v novověku zmocnilo myšlení, je, jak jsme viděli, charakteristické kladení protikladů, a zejména kladení se do protikladu vůči celku bytí. Toto myšlení je nyní „zabržděno“ (gehemmt) ve svém kladení distance vůči obsahu, „utrpí protiúder“ (Gegenstoss), ${ }^{28}$ a to proto, že to, „,co má ve větě formu

25 G. W. F. Hegel, Phänomenologie des Geistes, str. 58.

26 To je patrné již z toho, že Leibnizův termín vis repraesentativa překládá Wolff termínem Vorstellungskraft. K tomu srv. W. Röd, Novověká filosofie, II, přel. J. Karásek, Praha 2004, str. 318.

27 Z toho neplyne, že by Hegel proti tomuto modelu chtěl postavit nereprezentační model poznání. Hegelovi jde spíše o odhalení problémů spojených s jednostranností dané pozice. Zároveň je však zřejmé, že Hegel myšlenková určení nezkoumá z hlediska jejich referenciality, nebot' nereprezentují něco od sebe odlišného, nýbrž jen samy sebe. Tento nereprezentacionalismus se týká pouze pojmů logiky: „Hegel claims for himself the merit of having broken with all representational modes of thinking in order to settle in the standpoint of what he calls ,the Concept ${ }^{6}$, where thought becomes conscious of its identity with itself in each and everyone of the contents it thinks." Srv. B. Longuenesse, Hegel's Critique of Metaphysics, str. 13. K problému referenciality pojmů logiky srv. pozn. níže.

28 Tento pojem má podobnou funkci jako pojem „Anstoss“ u Fichta. Vyjadřuje střetnutí Já s Ne-Já, jež vede Já zpět k němu samému. „Anstoss“ je tedy i u Fichta 
predikátu, je substance sama““. ${ }^{29}$ Kladení distance vůči obsahu mělo podobu predikace, a to je nyní znesnadněno či přímo znemožněno tím, že formálnímu myšlení se zhroutí subjekt-predikátová forma.

$\mathrm{K}$ tomu lze říci ještě následující. Fenomenologie ducha je analýzou vědění $\mathrm{v}$ různých podobách jeho rozvoje a podoby vědomí jsou zároveň různými podobami vědění. Jednou z charakteristik tohoto projektu je konfrontace Hegelovy vlastní koncepce s koncepcemi alternativními, jež mají být ve svém epistemickém nároku, poznávat pravdu, vyvráceny. ${ }^{30}$ Uvedené místo lze tedy číst tak, že Hegel proti sobě staví model formálního a model uchopujícího myšlení, a to tak, že druhý model slouží k vyvrácení prvního: když se formálnímu myšlení ukáže, že to, co mělo za neotřesitelnou jistotu, neplatí - totiž uvedený predikační model, ve kterém je subjekt substrátem akcidentů, jež mu inherují a jež lze v predikacích chápat jako predikáty subjektu, kladeného do pozice gramatického subjektu -, je zmateno, protože to, co se mu ukáže, je nedostatečnost jeho modelu. To, co považovalo za akcident, je totiž ve skutečnosti substancí, a nemůže to tudíž jednoduše klást v propozicích na místo gramatického predikátu. To, co chápalo jako predikát, se mu proměnilo v subjekt propozice. I Hegel tedy pracuje s představou, že jako subjekt propozice je třeba klást to, co lze identifikovat jako substanci, zatímco predikátem propozice je akcident substance. Otázku po kritériích této identifikace, kterou řeší Kant svou naukou o schematismu čistých pojmů rozvažování, pak Hegel, zdá se, nechává v předmluvě otevřenou. Model, s nímž pracovalo formální myšlení, však byl nefunkční ze dvou důvodů: jednak neumožňoval uchopit obsah v jeho svébytnosti, jednak byl nedostatečný z hlediska sebevztahu subjektu. Byl tedy nefunkční epistemicky a sebereflexivně.

Postup formálního myšlení popisuje Hegel takto: „Počínajíc subjektem, jako by ležel v základu, zjišt’uje tím, že predikát je naopak substancí, že subjekt přešel v predikát, a tím je překonán.“31 Formální myšlení tedy vycházelo ze subjektu jako substance, jako z toho, co leží v základu, a nyní na základě konfrontace s uchopujícím myšlením vidí, že

„Gegenstoss“. Oba termíny mají navíc stejný slovní základ. Bylo by tudíž možné zvažovat, zda se Hegel u Fichta neinspiruje.

29 G. W. F. Hegel, Phänomenologie des Geistes, str. 58.

30 Na tuto skutečnost poukazuje Konrad Cramer. Srv. K. Cramer, Bemerkungen zu Hegels Begriff vom Bewusstsein in der Einleitung zur Phänomenologie des Geistes, in: R.-P. Horstmann (vyd.), Seminar. Dialektik in der Philosophie Hegels, Frankfurt a. M. 1978, 1989², str. 360-393.

31 G. W. F. Hegel, Phänomenologie des Geistes, str. 58. 
to, co považovalo za akcident, a tedy za predikát propozice, je naopak substancí, a tedy subjektem propozice, což korelativně znamená, že to, co považovalo za subjekt, je naopak akcidentem, a tedy predikátem propozice. To je smyslem typicky hegelovského a na první pohled zarážejícího výroku, že subjekt přešel (übergegangen) v predikát a je překonán (aufgehoben). Tato - jak bychom uvedenou změnu mohli provizorně nazvat - marginalizace subjektu propozice je oním terapeutickým prostředkem formálního myšlení. Možná je i následující interpretace: pro formální myšlení, jak jsme již ukázali, byl subjekt myšlení také subjektem všech propozic a obsah jeho predikátem. Zároveň byl subjekt substancí a obsah tedy jeho akcidentem, což docházelo svého - pro formální myšlení - adekvátního vyjádření v subjekt-predikátové propozici. Tím bylo již vždy nad obsahem. Nyní se situace obrátila: substanciálním se stal obsah a akcidentálním subjekt. Důsledek tohoto obratu vyjadřuje Hegel následujícím způsobem: „tím, že to, co se zdálo být predikátem, se stalo celou a samostatnou masou, nemůže myšlení svobodně bloumat sem a tam (frei herumirren), nýbrž je touto tíží zadrženo.“32 Uvedeným obratem je tedy myšlení přivedeno k tomu, že musí začít respektovat obsah v jeho samodanosti a nemůže s ním nakládat dle své libovůle.

Avšak vyjádření, že subjekt myšlení se stal akcidentem pojímaného obsahu, je př́liš silné. Jak jsme viděli, je charakteristickým rysem uchopujícího myšlení to, že subjekt myšlení zůstává i nadále hybatelem obsahu, avšak na rozdíl od formálního myšlení pouze v tom smyslu, že si obsah připisuje jako svůj a v tomto prripisování pouze pozoruje jeho vlastní pohyb. Do obsahu je tedy ponořeno jen a pouze $\mathrm{v}$ tomto oslabeném smyslu. V hegelovských termínech by se to dalo formulovat tak, že to, co je o sobě, se má stát něčím pro subjekt. Zdálo by se tedy, že to, co ztěžuje uchopujícímu myšlení jeho uchopování, je tento přechod do opačného extrému, kdy subjekt myšlení se stává akcidentem pojímaného obsahu. Myslící pojímání (denkendes Auffassen) zachází tedy, zdá se, příliš daleko.

Hegel má však na mysli ještě jiný problém. Popisuje ho takto:

„Jinak je položen do základu nejprve subjekt jako předmětné fixní Já; odtud postupuje nutný pohyb k rozmanitosti určení či predikátů; zde

32 Tamt. Tato metafora má stejný význam jako metafora Kantova: metafyzika byla až dosud pouhým tápáním - Herumtappen (Hegel: Herumirren). Srv. I. Kant, Kritik der reinen Vernunft, B VII. V místě B XV k tomu připojuje, že toto tápání bylo navíc, což je ještě horší, tápáním mezi pouhými pojmy. Termín ,,pouhý pojem“ (blosser Begriff) je označením takového pojmu, jehož vztah ke smyslovému názoru není zajištěn, a v tomto smyslu je neskutečnou myšlenkou. 
nastupuje na místo onoho subjektu vědoucí Já samo a je spojováním predikátů a jejich podržujícím subjektem. Avšak tím, že onen první subjekt sám vstupuje do určení a je jejich duší, nachází druhý subjekt, totiž vědoucí subjekt, to, s čím chce již být hotov a nad co chce přejít do sebe, ještě v predikátu, a namísto toho, aby mohl být v pohybu predikátů tím konajícím..., má co činit ještě s tím, co je Já obsahu, nemá být pro sebe, nýbrž má být spolu s obsahem. “"33

Výraz „předmětné fixní Já“ lze číst jako odkaz ke koncepci myslícího Já jako substance, je totiž položeno do základu, a funguje tudíž jako substrát. Tato koncepce je pak nutným pohybem - proč je tento pohyb nutný, je otázkou, na niž Hegel v předmluvě nedává odpověd’ - a je nahrazena jinou koncepcí, v níž myslící Já již není substancí, není zpředmětnělé, nýbrž je jednotící funkcí, a to jak predikátů v soudu, tak také rozmanitých určení (názoru).

Výše mluvil Hegel o tom, že subjekt je tím, že přešel v predikát, překonán - aufgehoben. To vzhledem k Hegelově interpretaci tohoto termínu musí znamenat, že subjekt interpretovaný jako substance je v subjektu interpretovaném jako vědoucí Já pozvednut na novou vyšší úroveň. Z perspektivy vývoje novověké filosofie to lze vyjádřit tak, že racionální psychologii, pro niž bylo myslící Já substancí, res cogitans, vystřídala transcendentální koncepce Já jako sjednocující funkce. Hegel je zjevně přesvědčen o tom, že transcendentální interpretace myslícího Já je jeho adekvátnějším pojetím.

Nyní chce Hegel vysvětlit, co bylo i na této koncepci nedostatečné. Toto vysvětlení naznačuje již zmíněná Hegelova teze z předmluvy, podle níž jde o to pojmout pravdu nejen jako substanci, ale také jako subjekt. To znamená, že záměrem Fenomenologie ducha je sloučit výklad myslícího Já jako substance s jeho transcendentálním pojetím jako jednotící funkce. V poslední kapitole Fenomenologie ducha se nachází místo, které mluví o stejné souvislosti: to, co bylo „předtím“ (vorhin) pojato jako jednota myšlení a rozlehlosti, bylo nyní třeba pojmout jako jednotu myšlení a času. ${ }^{34}$ Jde tedy o přechod od Spinozova pojetí substance jako jednoty kartesiánské res extensa a res cogitans ke Kantovu pojetí subjektivity jako jednoty myšlení a časovosti, přechod od subjektu jako substance k transcendentální subjektivitě. Programem Fenomenologie ducha je obě pojetí spojit a pojmout substanci jako subjekt, resp. subjekt

33 G. W. F. Hegel, Phänomenologie des Geistes, str. 59.

34 Tamt., str. 587. 
jako substanci. Hegel tedy chce restituovat interpretaci Já jako substance, avšak takovým způsobem, aby tím bylo transcendentální pojetí Já uchováno jeho pozvednutím na novou, vyšší úroveň.

Hegel chce říci, že deficitem transcendentální koncepce je to, že myslící Já v ní ještě nemůže být v plném smyslu pro sebe. Je stále spjato s obsahem takovým způsobem, že v něm ještě nemůže uchopit sebe samo tak, že obsah je jeho jinakostí, ve které je u sebe samého. Jinými slovy, transcendentální koncepci Já musí vystřídat pojetí Já jako ducha. Znamená to však, že myslícím pojímáním (denkendes Auffassen) je míněna transcendentální filosofie? Pokud by tomu tak bylo, pak by uchopování uchopujícímu myšlení (begreifendes Denken) ztěžovala tím, že by neumožňovala pojmout obsah jako pojem. To by znamenalo, že Hegel vidí slabinu transcendentální filosofie v její koncepci pojmu. Jak upozorňuje Werner Marx, pojmem Hegel obecně míní shrnující, apercipující činnost Já ${ }^{35}$ přičemž rozdíl oproti Kantovi spočívá v tom, že pro Hegela je pojem logos uskutečňující sebe sama jako subjekt, který konstituuje řád a inteligibilitu všeho, co je. ${ }^{36}$ Lze ukázat, že u Hegela lze rozlišovat (minimálně) dva významy pojmu „pojem“: jednou se jím míní samotná subjektivita, podruhé pojmy o věcech v nejširším smyslu. ${ }^{37}$ Byt' Hegel v předmluvě mezi oběma významy ne vždy dostatečně rozlišuje, musíme vzít toto rozlišení v potaz, protože jinak bude řada míst předmluvy nesrozumitelných. Vzhledem ke kontextu analyzovaného místa $v$ předmluvě by nedostatek transcendentálního pojetí pojmu musel mít odpovídající vyjádření v nedostatečnosti transcendentální teorie predikace. Je tomu tak?

\section{Subjekt a predikát}

Již vzhledem k nejednoznačnosti a složitosti Hegelova textu není snadné v závěru předchozí části položenou otázku zodpovědět. Pokusme se proto vyjít z toho, že krátce připomeneme Kantovu koncepci soudu.

35 W. Marx, Hegels Phänomenologie des Geistes. Die Bestimmung ihrer Idee in „Vorrede“ und „Einleitung“, Frankfurt a. M. 1971, str. 17.

36 Tamt., str. 18.

37 Srv. J. Karásek, Metoda jako sebevztah pojmu. K Hegelovu pojetí dialektické metody, in: Filosofický časopis, 5, 61, 2013, str. 681-704. Domnívám se, že je tř́eba rozlišovat mezi použitím termínu pojem v singuláru a v plurálu, přičemž na Kantův „pojem“ transcendentální apercepce navazuje Hegel tehdy, používá-li tento termín v singuláru. 
Již jsme zmiňovali Kantovu definici soudu v $\$ 19$ Kritiky čistého rozити. Soud je podle této definice způsob uvádění rozmanitosti jakkoliv definovaných představ pod jednotu apercepce. Na základě tohoto vztahu vzniká jednota předmětu zkušenosti a zároveň jednotné spojení predikátů v soudu - predikátů, které slouží jako deskriptory toho, co je dáno v empirickém názoru. Je to totiž jedna a táž funkce, jak zní Kantův argument, která zajišstuje jak jednotu propozice, tak jednotu rozmanitosti v názoru. ${ }^{38} \mathrm{~V}$ naší souvislosti je podstatné, že spojení rozmanitosti do jednoty předmětu zkušenosti je zároveň vytvořením empirického pojmu o tomto předmětu, nebot', jak zní Kantova definice objektu, objekt je to, do pojmu čeho, resp. v pojmu čeho je sjednocena daná rozmanitost názoru. ${ }^{39}$ Základem tohoto spojení je však čistý pojem rozvažování, kategorie. Protože je spojení rozmanitosti názoru do jednoty předmětu zkušenosti zároveň spojením do jednoty sebevědomí prožívajícího subjektu, jsou kategorie apriorními artikulacemi jednoty sebevědomí, jednoty Já.

Není vůbec jisté, zda Hegel chce rozporovat tuto aperceptivní souvislost Kantovy teorie soudu. Z programu vědy o logice se spíše zdá, že ji chce na nové úrovni podržet. ${ }^{40} \mathrm{Z}$ hlediska Hegelovy teorie pojmu jakožto čistého myšlenkového určení je však podstatné něco jiného, totiž to, že Kantovy kategorie mají fixní logický obsah (intenzi), který nelze v žádném případě uvést do takového pohybu, v rámci něhož jeden obsah svým vlastním dialektickým rozvojem, jehož hybatelem je určitá negace, generuje další obsah. Takovou představu by Kant musel odmítnout, protože by to znamenalo, že takto odvozené kategorie by nemohly být kmenovými pojmy čistého rozvažování, totiž kategoriemi. Důležité rovněž je, že podobně fixní charakter má i základní struktura propozice. Kant ji myslí v zásadě tradičně jako spojení dvou termínů, jednoho na místě gramatického subjektu, druhého na místě gramatického predikátu. Toto pojetí přichází ke slovu, když Kant říká, že výrazem spojení rozmanitosti pod objektivní jednotu apercepce je slůvko ,jest““. ${ }^{41}$ Základních propozičních struktur je dvanáct a v žádném př́ípadě nelze jednu převádět na druhou

\footnotetext{
38 I. Kant, Kritik der reinen Vernunft, A 79/B 104-105.

39 Tamt., B 137.

40 Ve Vědě o logice, v nauce o pojmu, Hegel o Kantově pojmu apercepce říká: „Patří k nejhlubším a nejsprávnějším náhledům, jež se nalézají v kritice rozumu, že jednota, která tvoří podstatu pojmu, je poznána jako pưvodní syntetická jednota apercepce, jako jednota ,Já myslím“ neboli jednota sebevědomí.“ Srv. G. W. F. Hegel, Wissenschaft der Logik, II, in: týž, Werke, VI, vyd. E. Moldenhauer - K. H. Michel, str. 254.
}

41 I. Kant, Kritik der reinen Vernunft, B 141-142. 
nebo ji z druhé nechat vznikat dialektickým pohybem. Představu, že subjekt přešel v predikát a je překonán, by Kant považoval v lepším případě za podivnou. Je tomu nepochybně tak, že je to tato statická zafixovanost propozicionálních struktur a kategorií, co je podle Hegela nedostatkem transcendentální teorie predikace, avšak nejen jejím: jde o nedostatek všech teorií predikace, které její strukturu považují za fixní. Je možné, že kromě Hegelovy jsou to všechny ostatní.

Na základě expozice v druhé části našeho článku by se mohlo zdát, že rozlišení na rovině ontologické, rozlišení substance a akcidentu, a rozlišení propoziční, rozlišení subjektu a predikátu, Hegel stírá nebo ho nedbá. Hegelova úvaha by potom byla zatîžena dvojznačností, k níž by ještě přistupovala dvojznačnost v pojmu subjektu, jak na ni upozorňuje Kant v rámci své kritiky racionální psychologie, subjektu jako substance a subjektu gramatického. ${ }^{42}$ Je tomu skutečně tak? Podíváme-li se na další rozvoj Hegelovy úvahy o spekulativní větě v předmluvě, zjistíme, že nikoli. Ve skutečnosti Hegel obě roviny explicitně rozlišuje. Pokračuje totiž těmito slovy: „Formálně lze řečené vyjádřit tak, že povaha soudu či věty vůbec, jež v sobě zahrnuje rozdíl subjektu a predikátu, je spekulativní větou ničena a identická věta, kterou se ona první stává, obsahuje protiúder (Gegenstoss) vůči onomu poměru.“43 Termínem „formálně“ se čtenáři dává najevo, že nyní traktuje Hegel sledovaný problém čistě na úrovni propozičních vztahů. Explicitně zde proti sobě staví, řekněme, tradiční propoziční strukturu a spekulativní propozici.

Pro tradiční propozici, jak ji drží ještě i Kant, je definitorní fixní poměr gramatického subjektu a gramatického predikátu, zatímco spekulativní věta, jak se Hegel pokusil ukázat v předchozích pasážích, je charakteristická tím, že vztah subjektu a predikátu právě není fixní, nýbrž, jak by to bylo lze s Hegelem vyjádřit, tekutý. Samotná propoziční struktura prodělává dialektický pohyb, spočívající v přesunu gramatického predikátu do pozice gramatického subjektu. Pro Kanta byl v čisté, neschematizované kategorii substance myšlen takový propoziční subjekt, který se již nemůže stát v žádné jiné propozici predikátem. ${ }^{44}$ Zdá se tedy, že přsesně tuto čistou myšlenku substanciality, definovanou propozičně,

42 Na tom se zakládá Kantova kritika paralogismu substanciality: pojem subjektu je v horní a v dolní premise použit jinak, jednak jako absolutní subjekt propozic a jednak jako absolutní subjekt ve smyslu myslící bytosti, a tudíž je celý sylogismus neplatný. Srv. tamt., A 348-351.

43 G. W. F. Hegel, Phänomenologie des Geistes, str. 59 (kurziva J. K.).

44 Srv. I. Kant, Kritik der reinen Vernunft, B 300-301/A 242-243. 
chce Hegel „překonat“, tj. podrobit pohybu, spočívajícímu v tom, že to, co v nějaké, patrně ne zcela libovolné propozici figuruje na místě gramatického predikátu, se stane gramatickým subjektem, který získá charakter zmíněné čisté myšlenky substanciality, a nebude již tedy moci být predikován o žádném jiném subjektu.

Takto by se dal vyjádřit závěr Fenomenologie ducha: v absolutním vědění dosahuje vědomí stavu, v němž již v sobě nenachází žádnou bezprostřednost, kterou by bylo třeba zprostředkovat tím, že se vědomí klade jako svůj vlastní objekt, že se zpředmětňuje. Toto zpředmětňování by se dalo propozičně vyjádřit tak, že subjekt, totiž vědomí samo, se klade jako predikát. Formuluje propozice, v nichž se klade na pozici gramatického subjektu a gramatického predikátu. Propozice tedy mají charakter sebevztahu. Před dosažením absolutního vědění to však vědomí neví. S absolutním věděním je tedy dosaženo stavu, v němž subjekt ví, že se již nemůže klást jako predikát v žádné další propozici, stal se absolutním subjektem. Je dosaženo identity vědění a předmětu či jistoty a pravdy. Vrátíme-li se zpět ke sledovanému výkladu, bude však především otázkou, co má Hegel na mysli, když mluví o tom, že tradiční propozice s fixní strukturou „se stává identickou větou“, přičemž tato identická věta „obsahuje protiúder vůči onomu poměru“.

Vyjděme z toho, že termínem ,identická věta“ míní Hegel - stejně jako Kant - analytickou propozici, a nechme prozatím stranou enigmatickou tezi, že tradiční propozice ,se stává“ identickou větou. ${ }^{45} \mathrm{Co}$

45 Z jednoho místa v článku o přirozeném právu z r. 1802 je patrné, že Hegel přinejmenším v této době skutečně stejně jako Kant ztotožňuje termíny identická a analytická věta. Místo ovšem vyznívá jako kritika analytických propozic. Hegel zde píše: „Ale protože materie formální jednoty, o níž mluvíme, není celkem protikladných [momentů], ale jen jednoho z protikladných [momentů], protože je určitostí, proto je také nutnost pouze formální analytická a vztahuje se pouze $\mathrm{k}$ formě identické neboli analytické věty, ve které lze určitost znázornit..." G. W. F. Hegel, Über die wissenschaftlichen Behandlungsarten des Naturrechts, seine Stelle in der praktischen Philosophie und sein Verhältnis zu den positiven Rechtswissenschaften, in: G. W. F. Hegel - F. W. J. Schelling, Kritisches Journal der Philosophie, Leipzig 1985, str. 372 (kurziva J. K.). Hegelova kritika je tedy následující: v analytické propozici není vyjádřena jednota protikladů, nýbrž jen jednota jednoho členu protikladné relace. Např. v propozici: „Všechna tělesa jsou rozlehlá“, je explikována jen jednota a určitost tělesa. Tato kritika by potom vyznívala ve prospěch syntetických propozic, nebot', a to lze triviálně doplnit, syntetická propozice je výrazem jednoty protikladů, a není tudíž jen výrazem jednostranné určitosti. To koreluje s tím, jak Hegel v článku o víře a vědění z téhož roku interpretuje způsob, jak Kant „vpravdě“ vyřešil svou hlavní kritickou otázku, jak jsou možné syntetické soudy a priori. K tomu srv. výše zmiňovaný článek Konrada Cramera, Spekulatives Denken und synthetisches Urteil 
z tohoto předpokladu vyplyne pro interpretaci? Jak známo, pro analytickou propozici podle Kanta platí, že termín kladený na místo gramatického predikátu je již před propozicí obsažen v termínu kladeném na místo gramatického subjektu jako součást jeho obsahu. Analytická propozice je tak explikací obsahu termínu kladeného na místo gramatického subjektu. Pro tuto propozici platí dvě charakteristiky: (i) spojení subjektu a predikátu je nutné $\mathrm{v}$ tom smyslu, že subjektu nelze připsat protiklad připsaného predikátu, aniž by byl porušen princip sporu. Je-li např. věta „Všechna tělesa jsou rozlehlá“ analytická propozice, pak věta: „Existuje nerozlehlé těleso" implikuje spor, a to s pojmem tělesa; (ii) v případě analytické propozice platí následující: věta „Všechna tělesa jsou rozlehlá“ implikuje větu „Něco rozlehlého je těleso.“" ${ }^{6}$ Tím se vůbec nenaznačuje existence těles, protože souvislost obou vět je výlučně logická, nikoliv existenční. Ukazuje se zde tedy, že termín, který je v první propozici kladen na místo gramatického predikátu, je v druhé propozici kladen na místo gramatického subjektu. Tím pochopitelně není nijak dotčena samotná subjekt-predikátová struktura propozice. To, co se pohybuje, jsou termíny, kladené do této struktury. Hegel nyní v citátu říká, že povaha (Natur) soudu v sobě zahrnuje rozdíl subjektu a predikátu.

Máme-li toto tvrzení dát do alespoň minimálně srozumitelné souvislosti s tezí, že tento soud se stává identickou větou, pak termín „rozdíl subjektu a predikátu“ musí mínit víc než jen jejich formální rozdíl, který je stejně platný jak pro analytické, tak pro syntetické propozice. Na rozdíl od analytických propozic pro syntetické propozice platí, že termín kladený na místo gramatického predikátu není obsažen v termínu kladeném na místo gramatického subjektu. Jejich spojení se tedy musí zakládat na jiné evidenci než na principu sporu. Podstatné je, že rozdíl subjektu a predikátu není v syntetické propozici pouze formální, tj. není dán jen samotnou formální strukturou propozice, nýbrž je obsahový: termíny kladené do formální subjekt-predikátové struktury syntetické propozice

a priori. Je možné, že Hegelovi se rozlišení analytických a syntetických propozic z hlediska jeho koncepce spekulativní věty nakonec jeví jako marginální. Používáme-li v rámci interpretace toto rozlišení, pak proto, že je to jeden z možných způsobů, jak alespoň do určité míry srozumitelně vysvětlit místa z předmluvy týkající se problému spekulativní věty. K tomu srv. též pozn. 50 a hlavní text níže.

46 To Kant vysvětluje v $\$ 14$, kde následně vysvětlí, že teprve na základě aplikace kategorie substance lze rozhodnout o tom, který z obou termínů je třeba klást na místo gramatického subjektu, resp. gramatického predikátu. Rozlišuje tak mezi logickým a transcendentálním použitím rozvažování. Srv. I. Kant, Kritik der reinen Vernunft, B 128-129. 
jsou před svým spojením v propozici obsahově diferentní. Před svým spojením v propozici spolu, takříkajíc, nemají nic společného.

Mějme např. propozici „Tento medvěd je bílý“. Termíny „medvěd“ a „bílý“ mohou existovat nezávisle na sobě, tj. jejich spojení v propozici není nutné. Kdyby bylo, pak bychom mohli formulovat propozici: „Všichni medvědi jsou bílí“ a tato propozice, pokud by byla pravdivá, by vyjadřovala takový stav světa, $v$ němž by nemohli existovat hnědí medvědi. ${ }^{47}$ Naproti tomu v analytické propozici: „Všechna tělesa jsou rozlehlá" nelze rozlehlost a těleso separovat tak, abychom mohli říci, že může existovat těleso bez rozlehlosti. Tím jsme samožrejmě vůbec nevysvětlili, co se míní tím, že propozice, pro niž platí syntetický typ diference, se stává identickou větou. Mohli bychom tím však vysvětlit, co má Hegel na mysli, když ř́ká, že identická propozice „obsahuje protiúder“" ve vztahu k té propozici, pro kterou platí obsahová diference subjektu a predikátu. Metaforou protiúderu se míní nejspíše to, že struktura identické věty destruuje strukturu první věty, a to v tom smyslu, že nyní ji lze podrobit konverzi, o které jsme mluvili. To, co bylo fixně kladeno na místo gramatického predikátu, nyní může být kladeno na místo gramatického subjektu.

Tento program destrukce fixní subjekt-predikátové formy propozice formuluje Hegel také nemetaforicky za pomoci svého charakteristického termínu: jde o to, že forma věty má být překonána - aufgehoben. ${ }^{48} \mathrm{Vez}$ meme-li opět v potaz význam tohoto termínu u Hegela, vyplyne z toho, že subjekt-predikátová struktura nemá být qua talis zrušena, nýbrž má být zachována pozvednutím na vyšší úroveň, a to zjevně uvedeným pohybem. V místě, které jsme analyzovali, to Hegel formuluje takto: „Ve filosofické větě nemá identita subjektu a predikátu znicotnit (vernichten) jejich rozdíl, který vyjadřuje forma věty, nýbrž jejich jednota má vzcházet jako harmonie.“49 Zde je patrné, že podle Hegela platí: (i) filosofické věty jsou věty spekulativní; (ii) ve spekulativní větě má být dosaženo identity subjektu a predikátu; (iii) této identity má být dosaženo při současném zachování rozdílu subjektu a predikátu tak, jak je vyjádřen ve standardní subjekt-predikátové propozici. $Z$ toho plyne: nemá-li být znicotněn, odstraněn rozdíl subjektu a predikátu i přses jejich identitu, musí to znamenat, že strukturou spekulativní věty bude identita identity a diference.

47 Kantovský problém apriorních, tj. nutných syntetických propozic můžeme pro zjednodušení ponechat stranou.

48 G. W. F. Hegel, Phänomenologie des Geistes, str. 61.

49 Tamt., str. 59. 
Přestože rozlišení analytických a syntetických propozic není pro Hegela pravděpodobně podstatné, lze tuto strukturu přiblížit na struktuře analytické propozice. Identický pojem je v ní rozložen do diference subjekt-predikátové struktury. Přesněji řečeno: původní identita pojmu je v ní rozložena na identitu pojmu na místě gramatického subjektu a diferenci tohoto pojmu vůči pojmu na místě gramatického predikátu, přičemž tato identita a diference je spojena do identity celku propozice. Schelling po roce 1800 tvrdí proti Kantovi v návaznosti na Leibnize, že pravda je vyjadřována jen $\mathrm{v}$ analytických propozicích. Bylo by zajímavou otázkou, zde Hegel chce zastávat podobnou pozici. ${ }^{50} \mathrm{~V}$ naší souvislosti je však podstatné něco jiného.

$\mathrm{Z}$ toho, co jsme řekli, je totiž patrné, že obor spekulativních vět nebude zcela universální, nýbrž bude omezen jen na jisté význačné typy propozic. I Hegelovi musí být jasné, že např. ve vztahu k větě: „Tento medvěd je bílý“ by byl uvedený dialektický pohyb absurdní, protože predikát bělosti není analyticky obsažen v pojmu medvěda a její pravda je verifikovatelná empiricky. Zdá se tedy, že do oboru spekulativních vět nebudou patřit syntetické aposteriorní propozice, nýbrž bude zahrnovat jen propozice apriorní. Ty byly podle Kanta charakteristické pro matematiku, čistou př́rodovědu a metafyziku. Vyjdeme-li z toho, že Hegelovým zvláštním zájmem nebylo řešit problematiku apriorních propozic v matematice a čisté přírodovědě, potvrdí se to, co jsme naznačili v předchozí části, totiž že svým pojetím spekulativní věty chce Hegel ošetřit problém metafyziky. Z toho však plyne, že způsob, jak s tímto

50 Zajímavé světlo na tuto souvislost vrhá Hegelův výrok o určité negaci v úvodu do Vědy o logice. Píše zde: „Jelikož to rezultující, negace, je určitou negací, má obsah. Je novým pojmem, avšak vyšším, bohatším pojmem než pojem předcházející, nebot' se obohatil o jeho negaci neboli protiklad, a obsahuje ho tedy, avšak víc než jen jeho, a je jednotou sebe a svého protikladu." Srv. G. W. F. Hegel, Wissenschaft der Logik. Lehre vom Sein, str. 38-39. Všimněme si: na základě dialektického pohybu se předchozí pojem stává součástí obsahu toho pojmu, který z něj rezultuje. Souvislost obou pojmů je nyní tedy analytická v Kantově smyslu, a jejich vztah bychom tedy museli vyjadřovat v analytických propozicích. Analytický vztah dvou pojmů není tedy jednoduše konstatovatelný, nýbrž je výsledkem jejich dialektického pohybu. Celá logika se uzavírá absolutní ideou, která v sobě obsahuje všechny předchozí pojmy, tj. všechny pojmy, které Hegel ve Vědě o logice rozvíjí. Pokud bychom tedy logiku odvíjeli zpět z jejího závěrečného rezultátu až k jejímu východisku, pak bychom formulovali sekvenci analytických propozic. Tyto soudy by tedy byly Erklärungsurteile v Kantově smyslu. Logika tedy postupuje synteticky v Hegelově smyslu, tj. metodou sjednocování odhalených protikladů, metodou, kterou jako první v rámci německé klasické filosofie rozvinul Fichte, avšak jejím výsledkem je všechny pojmy zahrnující jednota absolutní ideje. 
problémem naložil Kant, Hegela neuspokojuje. Nepovažuje tento problém za vyřrešený. Podle Hegela tedy nelze problém metafyziky vyřešit tím, že zodpovíme otázku, jak jsou možné syntetické soudy a priori. Jak zde ale může pomoci koncepce spekulativní věty?

Podívejme se na tento problém prizmatem Hegelova př́íkladu: „Bůh je bytí.“" ${ }^{11}$ Tento prŕíklad není zvolen náhodně. Tvoří centrální myšlenku přirozené theologie jakožto jedné ze speciálních disciplín racionalistické metafyziky. Stojí v základu ontologického důkazu boží existence, jenž se zakládal na tom, že pojem bytí je částí obsahu pojmu boha, a proto propozice „Bůh existuje“ pro ni byla analytická. Termín „existence“ není k termínu „bůh“ připojen na základě nějaké externí evidence, nýbrž výlučně na základě platnosti principu sporu: myslet boha jako neexistujícího by implikovalo spor.

Jak vykládá tuto větu Hegel? Nejprve upozorní na samožrejmost: predikátem věty je bytí. Avšak vzápětí připojí: predikát bytí má substanciální význam, je v něm vyjádřena esence (Wesen) boha. Bytí nemá být predikátem, nýbrž esencí - podstatou. Domnívám se, že Hegel tím má na mysli, že věta „Bůh je bytí“ vypovídá striktní identitu, je to tedy identická věta v silném smyslu: bůh je identický s bytím a bytí s bohem. Bůh je actus purus. Když Hegel následně řekne, že „Bůh tím přestává být tím, čím je na základě postavení ve větě, totiž fixním subjektem (das feste Subjekt)““, 52 je třeba to chápat jako poukaz k tomu, že standardní subjet-predikátová forma není $\mathrm{s}$ to adekvátně vyjádřit striktní identitu boha a bytí.

Nejprve je formulována propozice, která má standardní formu: máme dva termíny, boha a bytí, z nichž termín „,bůh“ klademe v propozici na místo gramatického subjektu a druhý, ,bytî“, na místo gramatického predikátu. Predikáty ve standardních propozicích vyjadřovaly akcidenty,jimiž byla určována substance na místě gramatického subjektu. Bytí však není akcidentem boha, dokonce není ani jeho esenciálním akcidentem, protože není vůbec žádným akcidentem. Není reálným predikátem, jak to formuluje Kant. Bůh není substancí, jíž by bytí inherovalo jako akcident či vlastnost. Bůh je bytí. Termín „bytí“ tedy nemůže být kladen na místo gramatického predikátu, protože touto predikací zaniká či se ztrácí to, čím bůh je, protože se sugeruje, že samotné bytí je jeho př́ípadkem. Tak tomu ale není. Termín „bytí“ by tudíž měl být kladen do pozice gramatického subjektu. To by však nedávalo smysl, protože pojem boha

51 G. W. F. Hegel, Phänomenologie des Geistes, str. 59.

52 Tamt. 
bychom museli klást na místo gramatického predikátu a museli bychom říci: Bytí je bůh, či přesněji řečeno: dávalo by to smysl jen za předpokladu striktní identity boha a bytí.

Tím se ovšem vracíme na začátek celé úvahy. Hegel se snaží ukázat, že ve standardní subjekt-predikátové propozici nelze podstatu boha adekvátně postihnout. Je totiž patrné, že myšlení chtějící vyjádřit podstatu boha jako bytí v izolované jednotlivé subjekt-predikátové propozici se začne točit v kruhu. Tím se ukazuje, že se vůbec ztrácí možnost použít pro vystižení podstaty boha standardní subjekt-predikátovou propozici, protože je zcela nejasné, co by v ní mělo být kladeno na místo gramatického subjektu, resp. predikátu. Termín „bůh“ tak ztrácí to, čím se v oné prvotní propozici zdál být, totiž fixním subjektem, jemuž lze v sérii propozic predikovat různé akcidenty. To podnikala racionalistická metafyzika ve své disciplíně nazvané přirozená theologie. Lékem ovšem nemůže být pokus ukázat, že propozice „Bůh je bytí“ je bud’ syntetická apriorní, nebo v ní není postižena žádná pravda. Východiskem terapie musí být spíše poznání, že propozice „Bůh je bytí““ vzata sama o sobě nemůže být adekvátním vyjádřením toho, co má být jejím prostřednictvím postiženo, totiž identita boha a bytí.

Postup, na základě něhož utrpí formální myšlení „protiúder“a, jak jsme naznačili, začne se točit v kruhu, popisuje Hegel takto:

„Místo toho, aby se myšlení při přechodu od subjektu k predikátu dostalo dál, cítí se, jelikož subjekt se ztrácí, spíše zabržděno a vrženo zpět k myšlence subjektu, protože ji postrádá; nebo jelikož predikát je sám vysloven jako subjekt, jako bytí, jako podstata (Wesen), jež vyčerpává povahu subjektu, nachází myšlení subjekt bezprostředně v predikátu.“53

Vyjádřeno souhrnně, Hegel chce říci, že formální myšlení je natolik navyklé na fixní subjekt-predikátovou formu propozice, že když se mu to, co považovalo v propozici za fixní subjekt, začne rozplývat, jelikož nachází subjekt bezprostředně v predikátu, nemůže se, takříkajíc, hnout z místa, cítí se v dalším postupu zabržděno a vrženo zpět k myšlence fixního subjektu a začne se točit v kruhu. O zabrždění mluvil Hegel již výše v místě, kde se zabýval představujícím myšlením, jež je zjevně totožné s myšlením formálním, jemuž jsme se věnovali v první části článku: když představující myšlení zjistí, nebo se mu nějakým jiným způsobem

53 Tamt. 
ukáže, že to, co považovalo za fixní, totiž standardní subjekt-predikátovou formu, takové není, protože to, co mělo ve větě formu predikátu, je substance sama, je ve svém postupu vpřed zabržděno, protože tím utrpělo protiúder. Tento důsledek dovozuje Hegel i zde: myšlení se cítí zabržděno ve svém postupu vpřed a nemůže již dál svobodně rezonovat, nýbrž je ponořeno do obsahu. Již v místech, kde Hegel rozlišoval tři typy myšlení, bylo patrné, že formálním myšlením míní racionalistickou metafyziku, jež se nenoří do obsahu, jak je sám svébytně utvářen, nýbrž je nad tento obsah nelegitimně povznesena a domnívá se, že se s ním epistemicky vypořádala tím, že ho vyslovovala ve standardních propozicích typu: „Bůh je bytí.“54

Je zjevné, že terapie, kterou Hegel navrhuje, je skeptická reflexe, která může vyjít např́klad z otázky: Je v propozici „Bůh je bytí“ skutečně adekvátně vyjádřena podstata boha? Tato skepse má za důsledek to, že formální myšlení ztrácí jistotu své nadřazenosti nad obsahem a noří se do něj, tj. uvědomuje si, že bude muset prohloubit svou myšlenkovou reflexi obsahu. To má Hegel na mysli, když píše: „Mínění zakouší, že je to míněno jinak, než jak mínilo, a tato korektura jeho mínění nutí vědění, aby se k větě vrátilo znovu, a nyní ji pochopilo jinak. " ${ }^{\text {55 }} \mathrm{Z}$ hlediska vývoje novověké filosofie splnila tuto skeptickou funkci Kantova kritika tím, že ukázala, že metafyzika se ve svých speciálních disciplínách zaplétala do neřešitelných problémů, antinomií, paralogismů a neplatných důkazů boží existence. To vedlo myšlení k důkladnějšímu zkoumání obsahů racionalistické metafyziky, a nakonec k přehodnocení samotné Kantovy

54 Už ve frankfurtském rukopisu Der Geist des Christentums Hegel ukazuje, „že každý pokus myslet božského ducha lidským rozvažováním vede k rozporu konečných určení, která se tím ruší". Srv. H.-J. Gawoll, Der logische Ort des Wahren. Jacobi und Hegels Wissenschaft vom Sein, in: A. Arndt - Ch. Iber (vyd.), Hegels Seinslogik. Interpretationen und Perspektiven, Berlin 2000, str. 93. „Ve frankfurtských rukopisech dospívá Hegel k závěru, že je třeba přijmout nadsmyslový pravdivostní obsah absolutního božského bytí, jejž však prostřednictvím vět pouhého rozvažovacího myšlení nelze pochopit,“ tamt., str. 95. Tato pravda má své místo v náboženském prožitku, jenž se vzpírá objektivaci, a je tudíž nepochopitelný. Tento náhled Hegel nejpozději v předmluvě k Fenomenologii ducha reviduje. Nejpozději nyní je přesvědčen o tom, že tuto pravdu lze explikovat ve spekulativních větách, tj. diskursivně. Všechna místa v předmluvě, v nichž Hegel kritizuje zbožné nadšení, pocit, názor apod. jako typ přístupu k této pravdě, lze tudíž číst také jako sebekritiku. Podle autora provádí Hegel tuto sebekritiku implicitně již ve spisu o diferenci (tamt., str. 96).

55 G. W. F. Hegel, Phänomenologie des Geistes, str. 60. 
kritiky. ${ }^{56}$ Metafyzika je možná jako věda, avšak její metoda nemůže být převzata $\mathrm{z}$ geometrie a její pravdy nemohou být vyjadřovány $\mathrm{v}$ izolovaných subjekt-predikátových propozicích. Její metoda musí být dialektická, k čemuž patří ukazovat přechody mezi zdánlivě fixními strukturami.

Této nemožnosti vyjadřovat filosofické, tj. metafyzické, tj. spekulativní pravdy v izolovaných propozicích si všímá Jan Patočka. Rozvádí v této souvislosti následující úvahu:

„Chce-li totiž reflexe absolutní syntézu (subjekt a objekt) vyjádřit formálně, pak to nedokáže jednou větou, nýbrž pouze dvěma, které jsou spolu ve vzájemném rozporu; $v$ jedné se vyjadřuje identita: $A=A, t j$. spojení; v druhé se vyjadřuje spojované, tj. rozdělené: A=B. Jako první věta abstrahuje od rozličnosti, tak druhá od sjednocení, identity; jako první vyjadřuje syntézu, tj. myšlení, tak druhá ne-myšlení, objekt.“57

Patočka zde přesně postihuje Hegelovu intenci, jak ji rozvíjí v návaznosti na Schellingovu identitní filosofii. Ve spekulativních větách jde

56 K tomu srv. K. Cramer, Peripetien der Ontologie. Wolff, Kant, Hegel, in: R. Bubner - W. Mesch (vyd.), Die Weltgeschichte - das Weltgericht. Stuttgarter Hegel-Kongress 1999, Stuttgart 2001, str. 176-207.

57 Srv. J. Patočka, Hegeluv filosofický a estetický vývoj, in: týž, Umění a čas, I, Sebrané spisy Jana Patočky, IV, vyd. D. Vojtěch - I. Chvatík, Praha 2004, str. 261. V jiném článku se Patočka k problému spekulativní věty vyjadřuje takto: „První typ pravdy odpovídá rozumu a jeho orgánem je spekulace; jeho výrazem je spekulativní věta, kde forma věty, tedy protikladoucí spojení, vytváří obsah a kde zdání oddělenosti subjektu od predikátu spočívá v pohybu, jejž nevykonává vnější subjekt, nýbrž který je pohybem samé věci, která má být předvedena.“ Srv. J. Patočka, Učení o minulém rázu umění, in: tamt., str. 323, pozn. d. Pro doplnění: druhým typem pravdy je pravda umění, pravda jakožto krása, třetím typem pravdy je pravda vyjádřená v obyčejném, konečném soudu, „který provádí konečný duchovní subjekt“ (tamt., str. 324, pozn. d). Domnívám se, že Patočka př́iliš a ne zcela přiměřeně zdůrazňuje theologický aspekt Hegelova myšlení. Podle něho je spekulativní věta vyjádřením „božského, stvořitelského myšlení" (tamt., str. 323, pozn. d). Interpretované pasáže z předmluvy tuto interpretaci nepotvrzují. Spíše lze z celkového kontextu i ze zadání samotné Fenomenologie ducha vyrozumět, že také spekulativní věta je výkonem konečného duchovního subjektu. Pro Hegela má nakonec poslední slovo nikoliv theologie, nýbrž filosofie. Základním záměrem filosofie náboženství je převést religiózní představy na pojmy. V jiném článku Patočka o konečném, obyčejném soudu, tj. o soudu se standardní subjekt-predikátovou formou, říká, že je jeho forma „odloučena od svého obsahu a spojuje se s ním pouze zvenčí, a to bez vnitřní nutnosti... Do svého obsahu myšlenka neproniká, neztotožňuje se s ním." Srv. J. Patočka, K vývoji Hegelových estetických názorů, in: tamt., str. 220. To odpovídá tomu, jak Hegel v předmluvě popisuje formální myšlení. Na závěr podotýkám, že všechny tři články spadají do poloviny 60 . let. 
o vyjadřování identity myšlení a bytí. Tuto identitu jakožto netriviální lze formulovat jen v sekvenci minimálně dvou propozic, jež jsou ve vztahu vzájemného protikladu, stejně jako se myšlení a bytí jeví formálnímu myšlení ponejprv jako protiklad. Tento protiklad je však nakonec pouze $\mathrm{v}$ akcentech: $\mathrm{v}$ jedné propozici $(\mathrm{A}=\mathrm{A})$ se akcentuje identita jako výraz myšlení, ve druhé $(\mathrm{A}=\mathrm{B})$ diference jako výraz bytí. Kantovo rozlišení syntetických a analytických propozic ztrácí ve vztahu k Hegelově koncepci spekulativní věty na významu. ${ }^{58}$ Proto podle Hegela nelze problém metafyziky vyřešit rozřešením otázky: Jak jsou možné syntetické věty a priori?

$\mathrm{V}$ předmluvě je místo, v němž se Hegel zabývá kritikou matematické metody. ${ }^{59} \mathrm{~V}$ úvodu do Vědy o logice se Hegel k této kritice vrací: „O této metodě jsem ... v předmluvě $\mathrm{k}$ Fenomenologii ducha řekl to podstatné... Spinoza, Wolff a jiní se nechali svést k tomu, že ji aplikovali i na filosofii a vnější chod nepojmové kvantity učinili chodem pojmu, což je samo o sobě sporné. “60 Stručně: matematická metoda je aplikovatelná legitimně jen na vztahy kvantit, což je v př́ípadě filosofie absurdní, protože ta se zabývá kvalitativními vztahy, jako je např. vztah boha a bytí. I zde je inspirace pozitivně kantovská, avšak jen do určité míry. Kant sice poukazuje na to, že matematickou metodu nelze v metafyzice aplikovat, avšak matematika je podle něho oproti metafyzice $\mathrm{v}$ epistemické výhodě, jež je dána tím, že své pojmy může bezprostředně konstruovat v názorech. ${ }^{61}$

58 V encyklopedické logice v § 171 je to patrné. Hegel zde píše: „Subjekt, predikát a určitý obsah čili identita jsou v soudu nejprve kladeny ve svém vztahu samy jako rozdílné, spadající mimo sebe. O sobě, tj. z hlediska pojmu, jsou však totožné, protože konkrétní totalita subjektu nezáleží v nějaké neurčité rozmanitosti, nýbrž jedině v jednotlivosti, v identitě zvláštního a obecného, a právě touto jednotou je predikát (§ 170). - Dále je ve sponě sice kladena totožnost subjektu a predikátu, ale nejprve jen v podobě pouhého abstraktního ,je'. Vzhledem k této totožnosti je tř̌eba subjekt klást také v určení predikátu, čímž nabývá i predikát určení subjektu a spona se naplňuje.“ Srv. G. W. F. Hegel, Malá logika, přel. J. Loužil, Praha 1992, str. 296. Soudy se nejprve jeví jako syntetické, přes totožnost pojmu - patrně pojmu předmětu, jenž je intencionálním objektem soudu -, jejímž výrazem je spona ,jest“", se myšlení dostane k tomu, že subjekt a predikát jsou totožné, a tudíž je jejich vztah analytický, avšak nikoli v Kantově smyslu, jelikož jde o obsaženost subjektu v predikátu et vice versa. Bylo by zajímavou otázkou, do jaké míry stojí za touto koncepcí Leibnizova představa, že všechny syntetické propozice lze v posledku převádět na analytické, a to díky identitě pojmu jednotlivé monády.

59 G. W. F. Hegel, Phänomenologie des Geistes, str. 42-45.

60 Týž, Wissenschaft der Logik, str. 37-38.

61 Srv. I. Kant, Kritik der reinen Vernunft, B 744-745/A 716-717. 
Pro Hegela to již žádná epistemická výhoda není, protože vztah pojmů $\mathrm{k}$ názorům není pro něj primární otázkou. A navíc $\mathrm{v}$ předmluvě $\mathrm{k}$ této kritice připojuje: „Evidence..., na kterou je matematika hrdá..., se zakládá na chudobě účelu... Jejím účelem či pojmem je veličina. To je právě nebytostný, nepojmový vztah.“62

Skeptický rozměr Hegelovy úvahy se dostává ke slovu, když Hegel říká: „Myšlení ztrácí tudíž natolik svou pevnou předmětnou půdu, kterou mělo na subjektu, nakolik je v predikátu k němu vrženo zpět a v něm nepřechází zpět do sebe, nýbrž do subjektu obsahu. “63 Řečeno jinak, rezonující formální myšlení je třeba skepsí uvést do stavu nejistoty stran jeho vědění a prostředkem $\mathrm{k}$ tomu je prokázaní toho, že základní filosofické, spekulativní nebo také metafyzické pravdy, např. že bůh je identický s bytím, nelze adekvátně postihnout pouze v samotné propozici: „Bůh je bytí.“ Tato propozice se dostává do konfliktu s jednotou pojmu, jak jsme to vyložili výše. Proto Hegel mluví o „konfliktu formy věty vůbec a ji ničící jednoty pojmu“" ${ }^{64}$

Formálním myšlením míní tedy Hegel to rozvažování (intellectus), jehož pomocí se racionalistická metafyzika snažila formulovat propozice o bohu, světě a duši a naivně se domnívala, že tak lze bezezbytku učinit pouze za použití standardní subjekt-predikátové struktury a, pokud možno, more geometrico.

\section{Jednota pojmu jako identita subjektu a substance}

Stav nejistoty, do něhož má být formální myšlení přivedeno, má být však z hlediska metafyziky pouze provizorní. Jedná se tedy o metodickou skepsi, o skepsi jako průchozí stadium filosofie.$^{65}$ Hegelův cíl je jiný. Již

\footnotetext{
62 G. W. F. Hegel, Phänomenologie des Geistes, str. 44.

63 Tamt., str. 60.

64 Tamt., str. 54.

65 Hegel se se skepticismem vyrovnává již záhy v článku $O$ vztahu skepticismu k filosofii, publikovaném v r. 1802 ve Filosofickém žurnálu, který Hegel vydával spolu se Schellingem. Zde se - s jistými výhradami - projevuje Hegelův pozitivní vztah k antickému skepticismu. Zejména se Hegel domnívá, že princip pyrrhónské skepse: panti logó logos isos antikeitai je obsažen v každé opravdové filosofii. Srv. G. W. F. Hegel, Verhältnis des Skepticismus zur Philosophie, in: týž, Werke, II, vyd. E. Moldenhauer K. M. Michel, Frankfurt a. M. 1970, str. 230. Zde Hegel nachází základní inspiraci ke svému pojetí spekulativní věty. Pyrrhónský skeptik ukazuje dogmatickému myšlení, řečeno s Hegelem, tekutost struktur, které toto myšlení považuje za fixní, a činí tak
} 
jsme ho naznačili v druhé části př́íspěvku. Přestože je Hegel v rámci své kritiky formálního myšlení pozitivně inspirován Kantem, text předmluvy přece jen, a to opakovaně, sugeruje představu, že na Kantově pojetí subjektivity bylo něco závadného. V druhé části jsme dospěli k tomu, že tato subjektivita se sice na rozdíl od formálního myšlení noří do obsahu tak, že již není jeho duší, jeho hybatelem, nýbrž tento obsah si jen připisuje jako svůj a v tomto připisování sleduje jeho vlastní imanentní pohyb, avšak nedokáže přejít z obsahu a s obsahem $k$ sobě. Veškerý její pohyb ve vztahu k obsahu spočívá v tomto sebeprripisování. Nedostatek Kantova pojetí nesouvisí jen s tím, že Kant tradicionalisticky trvá na tom, že pravdy lze vyjadřovat $\mathrm{v}$ propozicích $\mathrm{s}$ fixní subjekt-predikátovou strukturou. A nesouvisí ani jen s tím, že nedokáže, či lépe řečeno odmítá pojmout subjekt jako substanci, kvůli čemuž subjekt není ještě v pravém smyslu pro sebe, a to ve své jinakosti: když se vrací k sobě, nachází jen na obsah zcela prázdnou transcendentálně-formální představu Já. Souvisí to nakonec přece jen s pojmem pojmu. Již na začátku komentované pasáže Hegel zdůrazňuje, že při studiu vědy, tj. vědy o logice, je třeba zaměřit pozornost na pojem jako takový, přičemž vzápětí zdůrazňuje, že pojem působí rušivě jak na materiální, tak na formální myšlení. Tomu prvnímu přerušuje jeho „Zvyk běžet vpřed podél představ“ (Gewohnheit an Vorstellungen fortzulaufen) ${ }^{66}$ tomu druhému jeho rezonování v neskutečných myšlenkách, a to analyzovanou skeptickou metodou.

V př́ípadě uchopujícího myšlení je vztah k pojmu jiný. Zde platí, že pojem je pro ně vlastní podstatou předmětu (das eigene Selbst des Gegenstandes), tato podstata se podává jako dění, tedy jako pohyb předmětu. Pojem tudíž pro ně není „,klidovým subjektem, který nehybně nese akcidenty“, nýbrž tím, co se pohybuje a svá určení bere zpět do sebe. ${ }^{67}$ Co to pro Hegela znamená, že pojem bere svá určení zpět do sebe, jsme již interpretovali pomocí Kantova pojmu apercepce. Co však znamená, že pojem je vlastní podstatou (Selbst) předmětu, lze vyčíst z této formulace: „V přirozenosti toho, co je, že je ve svém bytí svým pojmem, spočívá vůbec logická nutnost. Ona sama je tím rozumovým a rytmem organického celku, je právě tak věděním o obsahu, jako je obsah pojmem a podstatou (Wesen).“68 Tato formulace zjevně vznáší nárok na obecnou

tím, že proti sobě staví dvě protikladné stejně platné propozice. K tomuto spisu srv. M. N. Forster, Hegel and Skepticism, Cambridge (Mass.) - London 1989.

66 G. W. F. Hegel, Phänomenologie des Geistes, str. 56.

67 Tamt., str. 57.

68 Tamt., str. 54-55. 
ontologickou platnost: pojem je podstatou všeho, co je. Z tohoto důvodu je Hegelova logika zároveň ontologií. Logická nutnost nepanuje jen v oblasti logických vztahů predikace a vyvozování, nýbrž je imanentním rytmem všeho, co je. Prostřednictvím pojmů víme o obsazích, ale obsahy nejsou v podstatě ničím jiným než pojmy. Hegel tak spojuje epistemologii s ontologií: jsou spojeny identitou toho, čím se zabývají.

Tímto Hegel postupuje daleko za Kanta. Kant je v zásadě ještě pojmový nominalista: pojmy jsou pro něj funkcemi mentálních aktů, jejichž prostřednictvím uchopujeme to, co samo pojmové povahy není. Tyto pojmy přitom můžeme používat jen tak, že je klademe jako predikáty možných soudů s fixní subjekt-predikátovou strukturou. Hegel na to čtenáře sice explicitně neupozorňuje, ale sám tento význam pojmu pojmu odlišuje od toho, který míní, když hovoří o pojmu ve smyslu subjektivity. Tento druhý význam má na mysli, když mluví o identitě (Einfachheit) myšlení, které obsahuje to, že má svou jinakost na sobě samém a je sebepohybem. Tato identita je „sebe samu pohybující a rozlišující myšlenkou, čistým pojmem" “ ${ }^{69}$ Když tedy Hegel v citovaném místě říká, že pojem není pro uchopující myšlení klidovým subjektem, který nehybně nese své akcidenty, nýbrž je tím, co se pohybuje a svá určení bere zpět do sebe, pak tím míní pojem v tomto druhém významu. Tento význam má rovněž na mysli, když naznačuje, že ve Fenomenologii ducha má být předveden návrat pojmu zpět do sebe (Zurückgehen des Begriffs in sich muss dargestellt sein). Čteme-li toto místo správně, pak to znamená, že duch je pojem a Fenomenologie ducha je popisem jeho návratu do sebe samého v jeho různých fázích, jimiž jsou podoby vědomí. Tak v závěrečné kapitole čteme: „V tomto vědění uzavřel tedy duch pohyb svého utváření, pokud bylo zatíženo nepřekonaným rozdílem vědomí. Získal čistý element své existence,

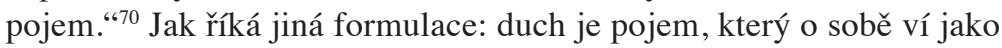
o pojmu ${ }^{71}$ a podoby jeho samého jako vědomí se mu nyní podávají jako určité pojmy. ${ }^{72} \mathrm{Na}$ jedné straně je tedy pojem jakožto subjektivita, která svým pohybem - jehož součástí je vztah k jinakosti - přechází zpět do sebe samé tím, že jinakost zniterní. Subjektivita je čistým pojmem. Na druhé straně jsou určité pojmy, jež byly od počátku př́ítomny v podobách vědomí jako jejich podstaty. V předmluvě spojuje Hegel

69 Tamt., str. 54.

70 Tamt., str. 588.

71 Tamt., str. 584.

72 Tamt., str. 588. 
tento program předvedení návratu pojmu zpět do sebe samého s překonáním fixní subjekt-predikátové formy věty. ${ }^{73}$

To, že subjektivita je pojem vůbec, nebo řečeno jinak, pojem pojmů, nacházíme i u Kanta. Tak v kapitole o paralogismech Kritiky čistého rozumu čteme:

„Nyní přicházíme k pojmu, jenž výše v obecném seznamu transcendentálních pojmů nebyl uveden, a přesto $\mathrm{k}$ nim musí být připočten, aniž bychom tím onu tabulku sebeméně změnili či prohlásili za nedostatečnou. Je jím pojem, nebo chcete-li raději soud: Já myslím. Snadno však vidíme, že je hybatelem (Vehikel) všech pojmů vůbec, a tudíž také transcendentálních..."74

Pojem Já do tabulky kategorií nepatří, protože není pojmem o předmětech možné zkušenosti, a přesto ke kategoriím patří, avšak pouze jako myslící, nikoliv jako myšlené. To lze vyjadřovat v propozicích typu: „Já myslím substanci, příčinu atd.“75 Kant však váhá, má-li Já označit jako pojem. Jednak již v citovaném místě naznačuje, že přiměřenější by bylo označovat je jako soud, a o několik stránek dále označení Já jako pojmu explicitně popře, když o něm prohlásí, že je: ,,jednoduchou, na obsah zcela prázdnou představou..., o které nelze ani říci, že je pojmem, nýbrž je pouhým vědomím, které všechny pojmy doprovází". ${ }^{76}$ Hegela od Kanta neodlišuje jen to, že při označení Já či subjektivity jako pojmu pojmů již nezaváhá, ${ }^{77}$ nýbrž především jiná a podstatnější systematická okolnost. U Kanta vůbec nemůže být řeči o tom, že by např́klad Kritika čistého rozumu měla být znázorněním návratu Já do sebe samého. Konec konců, kdyby se Kantovo transcendentální Já vrátilo samo k sobě, nalezlo by jen na obsah zcela prázdnou představu. Hegelovo Já se k sobě naopak vrátí i se vším, s čím se setkalo a co zniternilo. Není tedy na obsah zcela prázdnou představou, ale plností zkušenostního obsahu, který je zniterněním proměněn na pojmy. Duchem

73 Tamt., str. 61.

74 I. Kant, Kritik der reinen Vernunft, B 399/A 341.

75 Tamt., B 401/A 343.

76 Tamt., B 404/A 345-346.

77 Ve Vědě o logice, v nauce o pojmu, Hegel píše: „Pojem, nakolik dospěl k takové existenci, jež je sama svobodná, není ničím jiným než Já neboli čisté sebevědomí. Mám pojmy, tj. určité pojmy, avšak Já je čistý pojem sám, jenž jakožto pojem dospěl k existenci.“ G. W. F. Hegel, Wissenschaft der Logik, II, str. 253. 
(Geist) nemyslí Hegel v zásadě nic jiného než takto transformované transcendentální Já.

Výsledek fenomenologie ducha shrnuje Hegel v kapitole „Absolutní vědění“ takto: „Duch se nám ukázal [jako] pohyb Já (Selbst), jež se sobě zvnějšňuje a noří se do své substance a právě tak jako subjekt přešel z ní do sebe samého a učinil ji předmětem a obsahem..." "78 Je to tento pohyb sebezvnějšnění do substance světa a jeho překonání návratem do sebe samého se substancí jako předmětem a obsahem, co z Já dělá ducha, nebot' subjekt, který tímto pohybem zniternil substanci světa, je pojat jako substance. To lze nahlédnout ze dvou perspektiv, z perspektivy substance a z perspektivy subjektu, a formulovat $\mathrm{v}$ typicky hegelovských termínech bytí o sobě jakožto označení pro substancialitu a bytí pro sebe jakožto označení pro subjektivitu. Z perspektivy substance to znamená, že substance jakožto to, co bylo původně pro subjekt něčím o sobě, se stalo něčím pro sebe, a stalo se tedy subjektem; z perspektivy subjektu to naopak znamená, že jeho bytí pro sebe se stává bytím o sobě, a stává se tak substancí. To však pro Hegela neznamená, že na jedné straně by byla substance jako subjekt a proti ní by stál subjekt jako substance. To, co tím Hegel míní, je identita substance a subjektu. Pro tuto identitu má Hegel výraz „bytí o sobě a pro sebe“. Subjekt jako substance, resp. substance jako subjekt je bytím o sobě a pro sebe. Tento pohyb a jeho cílový stav lze vyjadřovat jen ve spekulativních propozicích, protože identitu subjektu a substance nelze adekvátně popsat pouze v izolované propozici: „Subjekt je substance“, resp. „Substance je subjekt“. Zaprvé v ní vůbec není vyjádřen zmíněný pohyb a jeho dvouaspektovost. Je formulována jen z hlediska dosaženého rezultátu, pro nějž je však pohyb - na jehož základě se k němu dospěje - bytostný. ${ }^{79}$ Metoda není separovatelná od pravdy. Zadruhé sugeruje představu, že Hegel chce jen opakovat to, co provedl Descartes a co Kant kritizoval jako paralogismus substanciality. Pak by ovšem jeho kritika formálního myšlení ztrácela smysl. Subjekt má být pojat jako substance, avšak toto pojetí nelze převést do podoby standardního úsudku, jak ho rekonstruuje a kritizuje

78 Týž, Phänomenologie des Geistes, str. 587-588.

79 I zde je pozoruhodná shoda s Fichtem. V Sonnenklarer Bericht Fichte nejprve popíše svou metodu. Ta spočívá v tom, že jsou rozvíjeny věty, které jsou následně vyvráceny, a to proto, že postupuje k syntézám prostřednictvím antitezí. Následně řekne, že „,celkově určený pravdivý rezultát ... se nachází pouze na konci“. J. G. Fichte, Sonnenklarer Bericht, str. 414-415. Naproti tomu jeho kritici a kontrahenti „hledají přirozeně jen tento rezultát“. Tamt., str. 415. Cesta, na které se k rezultátu dospělo, se pro ně nevyskytuje (tamt.). 
Kant. Fenomenologii ducha tak můžeme číst jako souvislost spekulativních vět, které s postupným nárůstem komplexity popisují genezi identity substance, bytí o sobě, a subjektu, bytí pro sebe, jejímž rezultátem je pojem ducha jakožto bytí o sobě a pro sebe. ${ }^{80}$

\section{ZUSAMMENFASSUNG}

$\mathrm{Zu}$ den schwierigsten Bestandteilen der Hegelschen Logik gehört die Lehre von dem spekulativen Satz. Ansätze zu dieser Lehre sind bereits in der Vorrede zur Phänomenologie des Geistes zu finden, und zwar in einem Textabschnitt, der vermutlich der schwierigste in der ganzen Vorrede ist. Die Absicht des Beitrags ist es, die Hegelschen Äußerungen in dem entsprechenden systematischen Kontext zu analysieren. Es wird herausgestellt, dass der systematische Kontext Hegels Auseinandersetzung mit Kants transzendentaler Logik darstellt. Dabei ist Hegel darauf aus, die Kantische Kritik der rationalistischen Metaphysik zunächst zu bestätigen, um sie dann jedoch im zweiten Schritt zugunsten einer neuen Gestalt der Metaphysik zu überwinden, derjenigen Metaphysik nämlich, für die der Begriff des Geistes als der Begriff von der Identität der Substanz und des Subjekts massgeblich ist und die nur mit Hilfe der spekulativen Sätze formuliert werden kann.

SUMMARY

One of the most difficult parts of Hegel's logic is his doctrine of the speculative sentence. Its roots can be found already in the preface to the Phenomenology of Mind, namely in the passage considered as the most challenging in the entire preface. The aim of the article is to analyse Hegel's assertions in the pertinent systematic context. We affirm that this systematic context is Hegel's confrontation with Kant's transcendental logic. Hegel's aim is, firstly, to confirm the Kantian critic of the rationalist metaphysics and, subsequently, to surmount it in order to put forward a new form of metaphysics. This metaphysics would be determined by the concept of mind as the identity of substance and subject and can be formulated only by means of the speculative sentence.

80 Článek byl realizován v rámci grantu poskytnutého Grantovou agenturou ČR, č. 16-11880S, s názvem: Duch, př́íroda a společnost v německé klasické filosofii. 